\title{
Toward better understanding of the human placenta: development of "disease-in-a-dish" models
}

Mana M. Parast

From Stillbirth Summit 2014

Medina, MN, USA. 19-21 June 2014

Many stillbirths result from pregnancy complications, whose root cause is abnormal development and function of the placenta [1]. In order to prevent stillbirths, we need to have a better understanding of how the human placenta develops, both in normal and abnormal pregnancies. This lack of understanding of the human placenta has recently been acknowledged, and "The Human Placenta Project" launched, by the National Institute of Child Health and Human Development (NICHD) [2]. In fact, the human placenta is difficult to study because of the lack of both "in vivo" animal models and placental cell lines able to be cultured "in vitro" in a tissue culture dish. Specifically, mice and rats have placentas which differ from the human both in structure and at the molecular level [3]; in addition, the human placental cell lines behave differently in culture, compared to the placental cells as they exist "in vivo" in the pregnant patient [4]. Over the last 5 years, our laboratory has set out to use human pluripotent stem cells (hPSCs) to model placental development in a dish [5]. "Pluripotent" stem cells have the ability to differentiate, or turn into, any cell type in the body, including the placental cell type, "trophoblast"[6,7]. While initially hPSCs had to be derived from human embryos, in 2007, Yamanaka et al. developed a method for generating such cells from any proliferative cell type [8]. hPSCs have now been derived from numerous cell types, including amnion cells of the placenta [9].

We have developed a method for step-wise differentiation of such hPSCs, first into trophoblast precursor cells and then into terminally differentiated, functional trophoblast, including multinucleated syncytiotrophoblast
(STB) and invasive extravillous trophoblast (EVT). These two cell types are the functional units of the placenta: STB carry out nutrient and gas exchange, while the EVT invade the maternal uterus and establish blood flow to the feto-placental unit. Our differentiation method is both reproducible and highly efficient, with $>95 \%$ of cells becoming trophoblast in the culture dish, based both on expression of specific genes and on functional assays such as secretion of the pregnancy hormone, hCG. We recently applied this method to hPSCs carrying a chromosomal aneuploidy, Trisomy 21 (T21). It is known that trophoblast isolated from T21 placentas have a defect in differentiation into multinucleated, hCG-secreting STB [10]. We asked whether this defect could be reproduced in culture when differentiating T21 hPSCs into trophoblast. We observed that T21 hPSCs indeed show delayed differentiation into functional STB, secreting significantly less hCG into the media compared to trophoblast derived from hPSCs with a normal karyotype. These results confirm the utility of hPSCs in modeling human placenta, both during normal development and in disease. We are currently collecting and banking amnion epithelial cells from placentas of patients with pregnancy complications, focusing on early-onset severe preeclampsia, which is highly associated with both maternal and neonatal morbidity and mortality. We believe that, once reprogrammed into hPSCs, these cells hold great promise, both in advancing our understanding of the mechanisms of placental dysfunction, and also in providing a platform for drug screening to reverse the disease phenotype. 


\section{References}

1. Flenady V, Koopmans L, Middleton P, Frøen JF, Smith GC, Gibbons K, Coory M, Gordon A, Ellwood D, Mcintyre HD, Fretts R, Ezzati M: Major risk factors for stillbirth in high-income countries: a systematic review and meta-analysis. Lancet 2011, 377(9774):1331-40.

2. Guttmacher AE, Maddox YT, Spong CY: The Human Placenta Project: placental structure, development, and function in real time. Placenta 2014, 35(5):303-4.

3. Malassiné A, Frendo JL, Evain-Brion D: A comparison of placental development and endocrine functions between the human and mouse model. Hum Reprod Update 2003, 9(6):531-9.

4. Janneau JL, Maldonado-Estrada J, Tachdjian G, Miran I, Motté N, Saulnier P, Sabourin JC, Coté JF, Simon B, Frydman R, Chaouat G, Bellet D:

Transcriptional expression of genes involved in cell invasion and migration by normal and tumoral trophoblast cells. J Clin Endocrinol Metab 2002, 87(11):5336-9.

5. Li Y, Moretto-Zita M, Soncin F, Wakeland A, Wolfe L, Leon-Garcia S, Pandian R, Pizzo D, Cui L, Nazor K, Loring JF, Crum CP, Laurent LC, Parast MM: BMP4-directed trophoblast differentiation of human embryonic stem cells is mediated through a DeltaNp63+ cytotrophoblast stem cell state. Development 2013, 140:3965-76.

6. Xu RH, Chen X, Li DS, Li R, Addicks GC, Glennon C, Zwaka TP, Thomson JA: BMP4 initiates human embryonic stem cell differentiation to trophoblast. Nat Biotechnol 2002, 20:1261-4.

7. Amita M, Adachi K, Alexenko AP, Sinha S, Schust DJ, Schulz LC, Roberts RM, Ezashi T: Complete and unidirectional conversion of human embryonic stem cells to trophoblast by BMP4. Proc Natl Acad Sci USA 2013, 110: E1212-21.

8. Okita K, Yamanaka S: Induction of pluripotency by defined factors. Exp Cell Res 2010, 316(16):2565-70.

9. Zhao HX, Li Y, Jin HF, Xie L, Liu C, Jiang F, Luo YN, Yin GW, Li Y, Wang J, $L i L S$, Yao YQ, Wang XH: Rapid and efficient reprogramming of human amnion-derived cells into pluripotency by three factors OCT4/SOX2/ NANOG. Differentiation 2010, 80(2-3):123-9.

10. Pidoux G, Gerbaud P, Cocquebert M, Segond N, Badet J, Fournier T, Guibourdenche J, Evain-Brion D: Review: Human trophoblast fusion and differentiation: lessons from trisomy 21 placenta. Placenta 2012, 33(Suppl A):S81-S86.

doi:10.1186/1471-2393-15-S1-A6

Cite this article as: Parast: Toward better understanding of the human placenta: development of "disease-in-a-dish" models. BMC Pregnancy and Childbirth 2015 15(Suppl 1):A6.

\section{Submit your next manuscript to BioMed Central and take full advantage of:}

- Convenient online submission

- Thorough peer review

- No space constraints or color figure charges

- Immediate publication on acceptance

- Inclusion in PubMed, CAS, Scopus and Google Scholar

- Research which is freely available for redistribution

Submit your manuscript at www.biomedcentral.com/submit
Ciomed Central 